\title{
Access and Resource Allocation to Education in Nigeria
}

\author{
Comfort R. Etor ${ }^{1}$, Ekpenyong E. Ekanem ${ }^{1} \&$ Mary A. Sule ${ }^{1}$ \\ ${ }^{1}$ Department of Educational Management, University of Calabar, Calabar, Nigeria \\ Correspondence: Comfort R. Etor, Department of Educational Management, University of Calabar, Calabar, \\ Nigeria.
}

Received: November 1, 2019

Accepted: December 19, 2019 Online Published: February 18, 2020

doi:10.5539/ies.v13n3p79

URL: https://doi.org/10.5539/ies.v13n3p79

\begin{abstract}
Access to education in Nigeria has attracted the attention of many Nigerians due to rising number of children and youths who are unable to gain admission into schools to actualize their educational and career dreams. Besides, there are also the issues of equitable and adequate resources to the existing schools to ensure qualitative education at all levels in Nigeria. This is the trust of this paper, as it examines the significance of access to education, equal educational opportunities, resource allocation to education and criteria for such allocations. The paper also attempts to highlight some problems and prospects of access and resource allocation to education in Nigeria.
\end{abstract}

Keywords: access, education, allocation, resources, opportunities

\section{Introduction}

Education for all by the year 2000AD, was a resounding slogan in Nigeria but when that target could not be attained, the target was further extended and tagged "education for all by the year 2015". That year came and ended without the realization of that vision. This tends to raise the question what really hindered the attainment of education for all Nigerians at those two instances? The answer to this question maybe approached from various perspectives. In this paper, an attempt shall be made to approach it from the perspective of "Access and resource allocation to education".

Access implies adequacy of educational opportunities for all who need education at all levels-primary, post-primary and tertiary. This has to take cognizance of the rate of growth in the population annually. This is where education should not be seen as the sole responsibility of government, but should include the involvement of individuals and other stakeholders in the private sector of the economy. This is why the Nigeria government allows the participation of the people in the running of private schools-from pre-primary to the tertiary levels (Federal Republic of Nigeria, 2013). However, in spite of such policies to enhance access to education, the situation still remain bleak as many children of school-going age, at all level, still lack access to education in this $21^{\text {st }}$ century. It must be noted that access to education at all levels is a right to Nigerians as contained in Nigerian Constitution (1999) revised edition 2011.

The second aspect of concern is resource allocation to education. This is very crucial to the attainment of the educational objectives at all levels. It further implies that an improvement in access to education naturally requires the corresponding increase in resource allocation to education. These shall be discussed in some details in this paper.

\subsection{The Meaning of Access in Education}

The Oxford Dictionary of English Etymology defines access as approach, admission, entrance and attack of disease. This implies that access may be used in relation to having opportunity to approach a person or situation. It may also be used in connection with the privilege of gaining admission into an institution of learning, restricted place or environment, and so on. In the context of this paper, access concerns having opportunity to gain admission or entrance into a school, college or university.

In this regard, Ehiametalor (2005) sees access to education as the opportunity to participate in the education sector, whether formal or informal. In the same vein, Oyebade, Oladipo, and Adetoro (2007) submit that access to education implies providing opportunities for those who are entitled to education to receive it. Akpan and Undie (2007) define access as the provision of equal opportunities for the qualified candidates, irrespective of circumstances of birth, ethnic group, religious affiliation or social status. This means that real access eliminates or 
should eliminate any form of discrimination against persons from certain group or class in the society.

Access in education therefore means availability of open doors for all intended and qualified candidates who wish to enter into existing schools to do so (Agile, 2018). It also implies that where there are inadequate number of schools at all levels, more schools should be established and equipped with adequate resources, to create opportunities for those who could not gain admission into the existing schools to do so. Access also means nearness of schools to those who wish to access it. In other words, access implies that nearness of schools at locations where potential learners could enroll is a significant factor since pupils or students from poor families may access it within a walking distance to save the costs of transportation to and from school.

\subsection{Significance of Access in Education}

Federal Republic of Nigeria (2014) recognizes access to education and training as not only basic human right, but also a key factor to social progress and in narrowing the gap between social economic groups and sexes. Furthermore, the policy thrust is to ensure access to education for all citizens at the primary, secondary and tertiary levels of education (Ene, 2005). This stresses the significance of access to education for all citizens considering the increasing trends in population growth in children of school-going age, and transition of completers at each level of education to another (from primary to secondary, and to tertiary levels, as the case may be). Besides, access to education does not only ensure that all willing and qualified candidates are offered admission into schools but also stimulates interest in those who were unwilling and less interested to embrace education as opportunities to develop themselves and become useful to themselves and the society in general. This is further anchored on the fact that access to education will reduce illiteracy and crime rates in the society.

\section{Types of Access to Education}

Each level of education determines the degrees of access to it, and that also depends on a number of factors, such as:

1) The number of local government areas in each state in Nigeria.

2) The number of existing schools.

3) Current enrolment profile pre-class and projected enrolment for 3 years.

4) Future expansion projections for, at least, three (3) years.

5) Reliable source of funding for capital and recurrent expenditure.

6) Accessibility (nearness) of schools within villages, clans within each local government area.

In this section, attempt shall be made to discuss access to primary education, post-primary and tertiary education, as well as adult and non-formal education which also include distance and correspondence education in Nigeria.

\subsection{Access to Primary and Secondary Education}

Primary education is the foundation laying level for other levels of education in any nation. In view of population growth, occasioned by increasing rate of births, the need for expansion of educational opportunities, in terms of increase in numbers of primary and secondary schools become imminent across the country. It is important to ensure that new schools (primary and secondary) are established where the existing schools do not provide the needed access to educational opportunities for children of school-going ages in any part of the local government, state and nation. A cursal look at Tables 1, 2 and 3 show enrolment by level of school in the nation from 2012-2016 with inconsistency in figures in primary 1-6, Js1-3 and SS1-3 in secondary schools.

Summary of Education Statistics: 2011-2016: 
Table 1. Primary school enrolment by state, year and gender: 2011-2016

\begin{tabular}{|c|c|c|c|c|c|c|c|c|c|c|c|c|c|c|c|}
\hline STATE & & 2012 & & & 2013 & & & 2014 & & & 2015 & & & 2016 & \\
\hline & $\mathrm{M}$ & $\mathrm{F}$ & $\mathrm{M}+\mathrm{F}$ & M & $\mathrm{F}$ & $\mathrm{M}-\mathrm{F}$ & M & $\mathrm{F}$ & $\mathrm{M}+\mathrm{F}$ & M & $\mathrm{F}$ & $\mathrm{M}-\mathrm{F}$ & $\mathrm{M}$ & $\mathrm{F}$ & $M-F$ \\
\hline Abia & 94329 & 94875 & 189204 & 134921 & 133156 & 268077 & 119287 & 174401 & 293688 & 95306 & 92439 & 187745 & 80827 & 78393 & 159420 \\
\hline Adamawa & 382793 & 333497 & 716290 & 381813 & 331387 & 713200 & 303513 & 278710 & 582223 & 34126 & 32930 & 67056 & 271920 & 247984 & 519904 \\
\hline Akwa Ibom & +48519 & 472984 & 921503 & 487776 & 519461 & 1007237 & 465437 & 494890 & 960327 & 488717 & 519622 & 1008339 & 24274 & 443875 & 868149 \\
\hline Anambra & 413050 & 425825 & 838875 & 112078 & 119872 & 231950 & 448686 & 467045 & 915731 & 402905 & 414168 & $\$ 17073$ & 427924 & 446180 & 874104 \\
\hline Bauchi & 414052 & 374159 & 788211 & 319682 & 431662 & 751344 & 429884 & 940488 & 1370372 & 467814 & 395336 & 863150 & 495327 & 421940 & 917267 \\
\hline Bayelsa & 154472 & 158373 & 312845 & 117767 & 119685 & 237452 & 68057 & 67976 & 136033 & 63220 & 61449 & 124669 & 57444 & 54330 & 111774 \\
\hline Benue & 437052 & 395872 & $\$ 32924$ & 475672 & 430680 & 906352 & 372018 & 332157 & 704175 & 530586 & 477819 & 1008405 & ¿83949 & 253594 & 537543 \\
\hline Bomo & NA & NA & $\mathrm{NA}$ & NA & NA & $\mathrm{NA}$ & $\mathrm{NA}$ & $\mathrm{NA}$ & $\mathrm{NA}$ & $\mathrm{NA}$ & $\mathrm{NA}$ & $\mathrm{NA}$ & 90611 & 249051 & 539662 \\
\hline Cross River & 170211 & 165669 & 335880 & 170211 & 165669 & 335880 & 219336 & 216059 & 435395 & 219336 & 216059 & 435395 & 100718 & 96858 & 197576 \\
\hline Delta & 248363 & 249989 & 498352 & 242401 & 239013 & 481414 & 253461 & 248288 & 501749 & 240405 & 238675 & 479080 & 194207 & 191310 & 385517 \\
\hline Ebonyi & 188088 & 191420 & 379508 & 188768 & 186364 & 375132 & 180312 & 184037 & 364349 & 191722 & 196938 & 388660 & 172984 & 174422 & 347406 \\
\hline Edo & 218130 & 218589 & $4 \vdots 6719$ & 186521 & 183426 & 369947 & 186438 & 184782 & 371220 & 187112 & 181960 & 369072 & 155857 & 152307 & $30 \$ 164$ \\
\hline Ekiti & 76236 & 76575 & 152811 & 76055 & 77080 & 153135 & $\$ 5551$ & 56088 & 111639 & 71171 & 71692 & 142863 & 77827 & 76966 & 154793 \\
\hline Enugu & 167809 & 164469 & 332278 & 159306 & 155479 & 314785 & 172219 & 163467 & 335686 & 160535 & 156805 & 317340 & 163268 & 158953 & 322221 \\
\hline FCT & 133254 & 132950 & 266204 & 159905 & 159540 & 319445 & 112892 & 110467 & 223359 & 119294 & .116771 & 236065 & 244214 & 245084 & 489298 \\
\hline Gombe & 304479 & 245679 & 550158 & 353826 & 291583 & 645409 & 282151 & 230913 & 513064 & 238955 & 195937 & & 249545 & 206026 & 455571 \\
\hline Imo & 559634 & 512904 & 1072538 & 726313 & 692474 & 1418787 & 481826 & 447084 & 928910 & 506486 & 470253 & 976739 & -89440 & 467887 & 957327 \\
\hline Jigawa & 306762 & 229925 & $5 ; 6687$ & 322287 & 245568 & 567855 & 331449 & 252571 & 584020 & 329371 & 254048 & 583419 & $\because 62802$ & 285345 & 648147 \\
\hline Kaduma & 651940 & 556851 & 1208791 & 714722 & 617345 & 1332067 & 704592 & 613216 & 1317808 & 698092 & 612625 & 1310717 & $\$ 10634$ & 726061 & 1536695 \\
\hline Kano & 1162037 & 1094270 & 2256307 & 1211811 & 1173373 & 2385184 & 1313143 & 1278240 & 2591383 & 1358500 & 1335095 & 2693595 & 1420782 & 1399611 & 2819393 \\
\hline Katsina & 943279 & 645277 & $158 \$ 556$ & 487920 & 680902 & $1168 s 22$ & 915303 & 674900 & 1590203 & 917848 & 676394 & 1594242 & 850043 & 679587 & 1529630 \\
\hline Kebbi & 312059 & 187822 & 499881 & 312059 & 187822 & 499881 & 287428 & 167873 & 455301 & 301696 & 177095 & 478791 & $\because 03762$ & 193790 & 497552 \\
\hline Kogi & 532555 & 532982 & 1065537 & 532555 & 532982 & 1065537 & 398168 & 398251 & 796419 & 441025 & 441136 & $\$ 82161$ & 272597 & 267577 & 540174 \\
\hline $\begin{array}{l}\text { Kwara } \\
\text { Kwara }\end{array}$ & 160123 & 149682 & 309805 & 142704 & 132571 & 275275 & 150064 & 140402 & 290466 & 154804 & 143168 & 297972 & 156352 & 143060 & 299412 \\
\hline Lagos & 533949 & 537880 & 1071829 & 553344 & $\$ 70952$ & 1124296 & 195973 & 204304 & 400277 & 479023 & 489226 & 968249 & 486924 & 496482 & 983406 \\
\hline Nasarawa & 189551 & 160853 & 350404 & 189551 & 160853 & 350404 & $17468 s$ & 145506 & 320194 & 190468 & 163315 & 353783 & $\angle 07018$ & 359434 & 766452 \\
\hline $\begin{array}{l}\text { Niger } \\
\text { Nits }\end{array}$ & 429810 & 330449 & & 413037 & 305878 & 718915 & 397283 & 309179 & 706462 & 385553 & 303168 & 688721 & 32214 & 339523 & 771737 \\
\hline Ogun & 288731 & 298504 & 587235 & 288459 & 291330 & 57978 & 280014 & 275218 & 555232 & 320085 & 319614 & 639699 & 501998 & $48 \$ 219$ & 990217 \\
\hline Ondo & 756459 & 789369 & 1545828 & 1103432 & 1119218 & 2222650 & 1069153 & 1081578 & 2150731 & 838629 & 838729 & 1677358 & 435397 & 411059 & 846456 \\
\hline Osun & 200461 & 200130 & 400591 & 200461 & 200130 & 400591 & 210661 & 209669 & 420330 & 210706 & 210325 & 421031 & 169462 & 168141 & 337603 \\
\hline Oyo & $50 \$ 139$ & 528663 & 1036802 & 512300 & 549387 & 1061687 & 651565 & 689263 & 1340828 & 742662 & 746962 & 1489624 & 96005 & 858352 & 1654357 \\
\hline Plateau & 275335 & 263360 & 538695 & 555750 & 520448 & 1076198 & 369311 & 365021 & 734332 & 297932 & 296759 & 594691 & .85238 & 278412 & 563650 \\
\hline Rivers & 150014 & 160433 & 310447 & 150014 & 160433 & 3104 & 165328 & 168001 & 333329 & 167632 & 162054 & 329686 & 121144 & 119412 & 240556 \\
\hline Sok & 7681 & 212923 & & 409384 & 224276 & 633 & 438864 & 254266 & 693130 & 442232 & 272199 & 714431 & 414849 & 262044 & 676893 \\
\hline Tara & 13908 & 271498 & 6154 & 339258 & 2719 & 611 & 339258 & 271999 & 611 & 330992 & 274131 & 6051 & 295235 & 243122 & 538357 \\
\hline Yobe & 411629 & 262547 & 674176 & 486438 & 322761 & 809199 & 424857 & 295790 & 720647 & 448782 & 317726 & 766508 & 213821 & 295682 & 709503 \\
\hline Zamfara & 202174 & 99128 & 301302 & 282392 & 152723 & 435115 & 287619 & 153309 & 440928 & 319588 & 176603 & 496191 & 319327 & 175968 & 495295 \\
\hline Total & 13167067 & 11726375 & 24893442 & 13500893 & 12657482 & 26158376 & 13255789 & 12545408 & 25801197 & 13393310 & 12049225 & 25442535 & $1: 435940$ & 12155241 & 25591181 \\
\hline
\end{tabular}

Note. Insurgency in the North East especially in Borno State affected data collection from 2011 to 2015 (Source: Nigeria Education Indicators, 2016).

Table 2. Junior secondary school enrolment by state, year and gender: 2012-2016

\begin{tabular}{|c|c|c|c|c|c|c|c|c|c|c|c|c|c|c|c|}
\hline \multirow[t]{2}{*}{ STATE } & \multicolumn{3}{|c|}{2012} & \multicolumn{3}{|c|}{2013} & \multicolumn{3}{|c|}{2014} & \multicolumn{3}{|c|}{2015} & \multicolumn{3}{|c|}{2016} \\
\hline & $\mathrm{M}$ & $\mathrm{F}$ & $\mathrm{M}+\mathrm{F}$ & $\mathrm{M}$ & $\mathrm{F}$ & $\mathrm{M}+\mathrm{F}$ & $\mathrm{M}$ & $\mathrm{F}$ & $\mathrm{M}+\mathrm{F}$ & M & $\mathrm{F}$ & $\mathrm{M}+\mathrm{F}$ & M & $\mathrm{F}$ & $\mathrm{M}+\mathrm{F}$ \\
\hline Abia & 14832 & 17743 & 32575 & 29580 & 36516 & 66096 & 27907 & 32397 & 60304 & 31755 & 35347 & 67102 & 15709 & 19633 & 35342 \\
\hline Adamawa & 65194 & 49845 & 115039 & 65194 & 49845 & 115039 & 65125 & 50101 & 115226 & 55127 & 46664 & 101791 & 56286 & 47614 & 103900 \\
\hline Akwa Ibom & 167075 & 181236 & 348311 & 163402 & 174981 & 338383 & 169039 & 181196 & 350235 & 177488 & 190263 & 367751 & 88500 & 92432 & 180932 \\
\hline Anambra & 37699 & 40327 & 78026 & 37699 & 40327 & 78026 & 40461 & 46377 & 86838 & 61269 & 68637 & 129906 & 46064 & 48548 & 94612 \\
\hline Bauchi & 123145 & 73836 & 196981 & 132890 & 75365 & 208255 & 89104 & 62195 & 151299 & 99089 & 70142 & 169231 & 112110 & 82239 & 194349 \\
\hline Bayelsa & 19823 & 18703 & 38526 & 24496 & 23447 & 47943 & 21162 & 20634 & 41796 & 21514 & 20674 & 42188 & 17879 & 17472 & 35351 \\
\hline Benue & 73132 & 60566 & 133698 & 73393 & 59193 & 132586 & 383199 & 298396 & 681595 & 234728 & 183168 & 417896 & 83618 & 71648 & 155266 \\
\hline Bomo & 49945 & 38088 & 88033 & $\mathrm{NA}$ & $\mathrm{NA}$ & $\mathrm{NA}$ & $\mathrm{NA}$ & $\mathrm{NA}$ & NA & $\mathrm{NA}$ & $\mathrm{NA}$ & $\mathrm{NA}$ & 66238 & 55018 & 121256 \\
\hline Cross River & 43748 & 45458 & 89206 & 91167 & 45458 & 136625 & 87120 & 88609 & 175729 & 87120 & 88609 & 175729 & 33075 & 31237 & 64312 \\
\hline Delta & $\$ 9714$ & 89206 & 178920 & 90593 & 92401 & 182994 & 92476 & 95499 & 187975 & 108651 & 110994 & 219645 & 79740 & 75388 & 155128 \\
\hline Ebonyi & 41987 & 42721 & 84708 & 58793 & 53078 & 111871 & 36604 & 37166 & 73770 & 36570 & 40427 & 76997 & 45849 & 50741 & 96590 \\
\hline Edo & 84013 & 92865 & 176878 & 70044 & 67797 & 137841 & 70044 & 67797 & 137841 & 85949 & 86814 & 172763 & 71213 & 71370 & 142583 \\
\hline Ekiti & 28603 & 28853 & 57456 & 29199 & 28750 & 57949 & 30126 & 25097 & 55223 & 29017 & 28972 & 57989 & 29073 & 29604 & 58677 \\
\hline Enugu & 101777 & 114475 & 216252 & 64147 & 73371 & 137518 & 67232 & 73633 & 140865 & 59619 & 70857 & 130476 & 55548 & 66259 & 121807 \\
\hline $\mathrm{FCT}$ & 55404 & 55362 & 110766 & 60656 & 60678 & 121334 & 54170 & 55855 & 110025 & 68217 & 71190 & 139407 & 45205 & 46122 & 91327 \\
\hline Gombe & 56468 & 41923 & 98391 & 62403 & 40489 & 102892 & 76918 & 56150 & 133068 & 49097 & 38853 & 87950 & 51228 & 41000 & 92228 \\
\hline Imo & 214294 & 213040 & 427334 & 470037 & 527246 & 997283 & 229553 & 229645 & 459198 & 237404 & 238163 & 475567 & 208537 & 208780 & 417317 \\
\hline Jigawa & 52691 & 38553 & 91244 & 66307 & 40651 & 106958 & 70163 & 41599 & 111762 & 63443 & 44392 & 107835 & 85958 & 59849 & 145807 \\
\hline Kaduna & 85875 & 73294 & 159169 & 78891 & 69903 & 148794 & 116650 & 97880 & 214530 & 47493 & 44514 & 92007 & 167595 & 138047 & 305642 \\
\hline Kano & 75309 & 58887 & 134196 & 67248 & 57112 & 124360 & 196487 & 147785 & 344272 & 242369 & 194125 & 436494 & 242398 & 199237 & 441635 \\
\hline Katsina & 124156 & 81271 & 205427 & 152214 & 127452 & 279666 & 121537 & 93878 & 215415 & 144755 & 102746 & 247501 & 154668 & 111514 & 266182 \\
\hline Kebbi & 91372 & 47120 & 138492 & 91372 & 47120 & 138492 & 96481 & 47175 & 143656 & 99032 & 46882 & 145914 & 95598 & 47804 & 143402 \\
\hline Kogi & 39264 & 37844 & 77108 & 39269 & 37847 & 77116 & 43408 & 41896 & 85304 & 44101 & 42549 & 86650 & 33520 & 31933 & 65453 \\
\hline Kwara & 64240 & 52794 & 117034 & 60626 & 54674 & 115300 & 17016 & 15452 & 32468 & 17896 & 16842 & 34738 & 65939 & 63188 & 129127 \\
\hline Lagos & 69669 & 72421 & 142090 & 242569 & 255416 & 497985 & 156237 & 161375 & 317612 & 223337 & 238263 & 461600 & 232384 & 239663 & 472047 \\
\hline Nasarawa & 29920 & 26374 & 56294 & 29920 & 26374 & 56294 & 12771 & 12301 & 25072 & 48968 & 38687 & 87655 & 53689 & 46433 & 100122 \\
\hline Niger & 130297 & 84061 & 214358 & 116669 & 73085 & 189754 & 109648 & 74982 & 184630 & 107474 & 71654 & 179128 & 124255 & 93121 & 217376 \\
\hline Ogun & 116348 & 116929 & 233277 & 128072 & 128650 & 256722 & 136929 & 133604 & 270533 & 146721 & 146109 & 292830 & 135093 & 133614 & 268707 \\
\hline Ondo & 98403 & 101703 & 200106 & 98928 & 102561 & 201489 & 101063 & 99417 & 200480 & 110753 & 105718 & 216471 & 59274 & 60632 & 119906 \\
\hline Osun & 86079 & 84077 & 170156 & 84447 & 82909 & 167356 & 69386 & 68765 & 138151 & 12398 & 13281 & 25679 & 63876 & 62490 & 126366 \\
\hline Oyo & 115796 & 116656 & 232452 & 119757 & 120147 & 239904 & 142754 & 145890 & 288644 & 166199 & 165096 & 331295 & 146750 & 148830 & 295580 \\
\hline Plateau & 59348 & 52708 & 112056 & 88250 & 78906 & 167156 & 55502 & 48896 & 104398 & 61491 & 54771 & 116262 & 52347 & 47848 & 100195 \\
\hline Rivers & 63441 & 69652 & 133093 & 63441 & 69652 & 133093 & 74331 & 81672 & 156003 & 72143 & 78108 & 150251 & 55633 & 59692 & 115325 \\
\hline Sokoto & 54770 & 22021 & 76791 & 55067 & 28041 & 83108 & 57875 & 32612 & 90487 & 58732 & 32337 & 91069 & 128906 & 71132 & 200038 \\
\hline Taraba & 50537 & 33284 & 83821 & 50536 & 33283 & 83819 & 56165 & 37035 & 93200 & 40638 & 31007 & 71645 & 67371 & 49218 & 116589 \\
\hline Yobe & 75874 & 58641 & 134515 & 41516 & 29672 & 71188 & 79152 & 57528 & 136680 & 46716 & 29227 & 75943 & 42643 & 32009 & 74652 \\
\hline Zamfara & 66504 & 28244 & 94748 & 68250 & 29606 & 97856 & 57675 & 31135 & 88810 & 62836 & 34100 & 96936 & 68041 & 34973 & 103014 \\
\hline TOTAL & 2816746 & 2460781 & 5277527 & 3221959 & 2946805 & 6168764 & 3311470 & 2891624 & 6203094 & 3260109 & 2920182 & 6180291 & 3181810 & 2786332 & 59681 \\
\hline
\end{tabular}

Note. Insurgency in the North especially in Borno State affected data collection from 2013 to 2015 (Source: Nigeria Education Indicators, 2016). 
Table 3. Senior secondary school enrolment by state, year and gender: 2011-2016

\begin{tabular}{|c|c|c|c|c|c|c|c|c|c|c|c|c|c|c|c|}
\hline & M & $\mathrm{F}$ & $\mathrm{M}+\mathrm{F}$ & M & $F$ & $\mathrm{M}+\mathrm{F}$ & M & $\mathrm{F}$ & $\mathrm{M}+\mathrm{F}$ & M & $\mathrm{F}$ & $\mathrm{M}+\mathrm{F}$ & M & $\mathrm{F}$ & $\mathrm{M}+\mathrm{F}$ \\
\hline & 14689 & 18119 & 32808 & 23529 & 26632 & 50161 & 20,700 & 24,447 & 45,147 & 20,768 & 21,263 & 42,031 & 12580 & 15917 & 28497 \\
\hline Adamawa & 47287 & 31854 & 79141 & 47287 & 31854 & 79141 & 43,743 & 33,614 & 77,357 & 44,636 & 34,300 & 78,936 & 45546 & 34999 & 80545 \\
\hline Akwa Ibom & 132126 & 139717 & 271843 & 140336 & 140911 & 281247 & 147,357 & 147,961 & 295,318 & 154,729 & 155,368 & 310,097 & 130116 & 79775 & 209891 \\
\hline Anambra & 26357 & 32168 & 58525 & 29777 & 31635 & 61412 & 25,212 & 29,253 & 54,465 & 27,000 & 29,939 & 56,939 & 27167 & 31606 & 58773 \\
\hline Bauchi & 76071 & 35273 & 111344 & 78460 & 73092 & 151552 & 67,943 & 31,215 & 99,158 & 65,721 & 40,402 & 106,123 & 75130 & 47416 & 122546 \\
\hline Bayelsa & 22399 & 18149 & 40548 & 22399 & 18149 & 40548 & 24,325 & 21,140 & 45,465 & 24,259 & 21,597 & 45,856 & 16986 & 15462 & 32448 \\
\hline Benue & 73385 & 53756 & 127141 & 73385 & 53756 & 127141 & 194,801 & 149,323 & 344,124 & 245,468 & 188,753 & 434,221 & 53788 & 44421 & 98209 \\
\hline Bomo & 83661 & 49786 & 133447 & 83661 & 49786 & 133447 & $\mathrm{NA}$ & $\mathrm{NA}$ & $\mathrm{NA}$ & $\mathrm{NA}$ & $\mathrm{NA}$ & $\mathrm{NA}$ & 39726 & 28810 & 68536 \\
\hline Cross River & 41584 & 38680 & 80264 & 41584 & 38680 & 80264 & 67,092 & 69,579 & 136,671 & 67,092 & 69,579 & 136,671 & 25953 & 25244 & 51197 \\
\hline Delta & 82567 & 73709 & 156276 & 76839 & 74286 & 151125 & 76,839 & 74,286 & 151,125 & 54,200 & 52,281 & 106,481 & 62726 & 61847 & 124573 \\
\hline Ebonyi & 53209 & 55886 & 109095 & 82567 & 73709 & 156276 & 23,401 & 25,621 & 49,022 & 31,190 & 34,886 & 66,076 & 35808 & 40304 & 76112 \\
\hline Edo & 134258 & 133032 & 267290 & 134258 & 133032 & 267290 & 63,286 & 64,812 & 128,098 & 48,550 & 48,385 & 96,935 & 59787 & 62744 & 122531 \\
\hline Ekiti & 27099 & 26000 & 53099 & 25416 & 24806 & 50222 & 26,185 & 19,373 & 45,558 & 28,283 & 27,891 & 56,174 & 25179 & 25006 & 50185 \\
\hline Enugu & 61988 & 74868 & 136856 & 61497 & 71874 & 133371 & 60350 & 74,927 & 135,277 & 53,120 & 66,113 & 119,233 & 48796 & 60996 & 109792 \\
\hline FCT & 30277 & 31369 & 61646 & 30277 & 31369 & 61646 & 27,437 & 29,118 & 56,555 & 31,858 & 36,105 & 67,963 & 27966 & 29672 & 57638 \\
\hline Gombe & 46799 & 29524 & 76323 & 46799 & 29524 & 76323 & 51,776 & 38,670 & 90,446 & 38,742 & 24,994 & 63,736 & 38081 & 27155 & 65236 \\
\hline Imo & 281566 & 245482 & 527048 & 281566 & 245482 & 527048 & 207,783 & 217,630 & 425,413 & 232,477 & 245,488 & 477,965 & 179880 & 205016 & 384896 \\
\hline Jigawa & 47754 & 11174 & 58928 & 56482 & 23070 & 79552 & 56,818 & 29,405 & 86,223 & 52,722 & 25,864 & 78,586 & 55006 & 31371 & 86377 \\
\hline Kaduna & 54884 & 47246 & 102130 & 51096 & 44174 & 95270 & 89,620 & 68,754 & 158,374 & 74,464 & 61,788 & 136,252 & 89908 & 76358 & 166266 \\
\hline Kano & 17193 & 18858 & 36051 & 17193 & 18858 & 36051 & 149,909 & 87,604 & 237,513 & 177,467 & 120,731 & 298,198 & 161304 & 111502 & 272806 \\
\hline Katsina & 89061 & 43805 & 132866 & 89061 & 43805 & 132866 & 89,229 & 44,315 & 133,544 & 103,954 & 52,279 & 156,233 & 106949 & 62457 & 169406 \\
\hline $\mathrm{Kebbi}^{* *}$ & 93424 & 71573 & 164997 & 125778 & 84893 & 210671 & $\mathrm{NA}$ & $\mathrm{NA}$ & $\mathrm{NA}$ & NA & $\mathrm{NA}$ & NA & 55369 & 23125 & 78494 \\
\hline Kogi & 35515 & 30378 & 65893 & 35515 & 30378 & 65893 & 39,622 & 34,635 & 74,257 & 40,681 & 35,601 & 76,282 & 29454 & 26917 & 56371 \\
\hline Kwara & 50426 & 41048 & $\$ 1474$ & 49172 & 43274 & 92446 & 44,337 & 38,860 & 83,197 & 52,519 & 47,019 & 99,538 & 54752 & 48695 & 103447 \\
\hline Lagos & 190633 & 197402 & 388035 & 196656 & 202790 & 399446 & 115,601 & 132,168 & 247,769 & 183,671 & 191,285 & 374,956 & 175485 & 185379 & 360864 \\
\hline Nasarawa & 79245 & 59279 & 138524 & 79245 & 59279 & 138524 & $\mathrm{NA}$ & $\mathrm{NA}$ & $\mathrm{NA}$ & 50,454 & 37,640 & 88,094 & 49305 & 37813 & 87118 \\
\hline Niger & 105192 & 62474 & 167666 & 105192 & 62474 & 167666 & 96,453 & 65,472 & 161,925 & 91,850 & 63,101 & 154,951 & 93565 & 69493 & 163058 \\
\hline Ogun & 107332 & 105616 & 212948 & 114299 & 117991 & 232290 & 111,192 & 110,174 & 221,366 & 125,064 & 125,979 & 251,043 & 113185 & 119309 & 232494 \\
\hline Ondo & 73608 & 70139 & 143747 & 73608 & 70139 & 143747 & 75,101 & 71,903 & 147,004 & 75,259 & 71,899 & 147,158 & 53854 & 53841 & 107695 \\
\hline Osun & 78410 & 75535 & 153945 & 74979 & 71681 & 146660 & $\mathrm{NA}$ & $\mathrm{NA}$ & $\mathrm{NA}$ & 70,065 & 68,605 & 138,670 & 44190 & 40974 & 85164 \\
\hline Oyo & 102155 & 99206 & 201361 & 105682 & 111248 & 216930 & 125,012 & 127,762 & 252,774 & 140,755 & 147,412 & 288,167 & 119528 & 123603 & 243131 \\
\hline Plateau & 50582 & 41955 & $\$ 2537$ & 51167 & 42055 & 93222 & 50,245 & 41,449 & 91,694 & 55,501 & 47,524 & 103,025 & 44582 & 38930 & 83512 \\
\hline Rivers & 72029 & 80357 & 152386 & 72029 & 80357 & 152386 & $\mathrm{NA}$ & $\mathrm{NA}$ & $\mathrm{NA}$ & NA & NA & $\mathrm{NA}$ & 51085 & 62424 & 113509 \\
\hline Sokoto & 79070 & 29040 & 108110 & 79070 & 29040 & 108110 & 48,230 & 22,755 & 70,985 & 39,411 & 20,610 & 60,021 & 50240 & 27848 & 78088 \\
\hline Taraba & 38061 & 25078 & 63139 & 38061 & 25078 & 63139 & $\mathrm{NA}$ & $\mathrm{NA}$ & $\mathrm{NA}$ & 26,588 & 20,717 & 47,305 & 29375 & 21955 & 51330 \\
\hline Yobe $e^{* *}$ & 42167 & 19411 & 61578 & 42167 & 19411 & 61578 & 47,776 & 19,821 & 67,597 & 49,469 & 26,373 & 75,842 & 28517 & 15063 & 43580 \\
\hline Zamfara & 54805 & 20908 & 75713 & 65871 & 22273 & 88144 & 53,808 & 25,260 & 79,068 & 51,539 & 19,647 & 71,186 & 106324 & 44670 & 150994 \\
\hline Total & 2696868 & 2237854 & 4934722 & 2801960 & 2350845 & 5152805 & $2,321,183$ & $1,971,306$ & $4,292,489$ & $2,629,526$ & $2,281,418$ & $4,910,944$ & 2417192 & 2058117 & 4475309 \\
\hline
\end{tabular}

Note. Borno State was worst hit in insurgency this made it difficult to get the Enrolment for the years 2014 and 2015 (Source: Nigeria Education Indicators, 2016)

There are however, some justifiable reasons for these inconsistencies in enrolment figures. It has been rightly observed that the problem of insurgency affected pupils' enrolment in some Northern States, especially Borno State. Again, some states failed to send data on school's enrolment to the education data bank for compilation e.g. Kebbi, Osun, Rivers and Taraba States. More importantly, and a great concern is inadequacy of access to education which negatively affected enrolment of pupils who were denied opportunity to enroll. This is of great concern since education is the right of every child and youth in Nigeria. As pointed out by Aremu (2014), access to education in some States in the northern part of Nigeria is about $19.91 \%$, while the southern part recorded as high as $95 \%$. Gender disparities also exist as female enrolment was lower than male enrolment in the north (Matera, 2014), while in the southern part, female enrolment was generally higher than male enrolment. It is a dangerous trend to allow such lapses to persist in the education sector, since it implies risking the future of our young people at the primary and secondary school levels, if denied the right to early education as preparation for tertiary education and job opportunities. As rightly stressed by Federal Republic of Nigeria (2014), education and training is not only basic human right but also a key factor to social progress and in narrowing the gap between social economic groups and sexes. This is why government at all levels should ensure that such laudable policies are implemented by providing access to basic education for all children in Nigeria.

Furthermore, the Day of an African Child is celebrated on the $16^{\text {th }}$ June of every year with emphasis on ensuring that every child is given the right to education and moral upbringing in the society. Nigeria, like other African countries celebrated this great event on $16^{\text {th }}$ June, 2018, but how many of Nigerian children have access to education at all levels? This means that the 13.2 million out-of-school children as stated by Hindi (2019) must have access to education to make this celebration worthwhile. Even the Child Right Act on the rights of every child according to Kufre and Kufre (2013) stipulates the following:
1) Every child has the right to survival and development.
2) Every child has the right to be given a name.
3) Right to freedom of association and peaceful assembly.
4) Right to freedom of thought conscience and religion.
5) Right to private and family life.
6) Right to freedom of movement, subject to parental control. 
7) Right to freedom from discrimination.

8) Right to the dignity of the child.

9) Right to health and health services.

10) Every child is entitled to rest and leisure and to recreation, and cultural activities.

11) Every child has the right to parental care, protection and maintenance.

12) Right of a child to free, compulsory and Universal Primary Education, etc.

13) Right of a child in need of special protection measures.

14) Right of the unborn child to protection against harm, etc. (pp. 75-86).

It is obvious that the above provisions of the Child Right Act have a lot of implications for resource allocations to education by all the tiers of government. This will ensure the provision of the necessary facilities for quality education and training that would maximize their all-round potentials for growth and development.

\subsection{Access to Tertiary Education}

The demand for tertiary education in Nigeria in the $21^{\text {st }}$ century is very high (Zwalchir, 2007), yet access to it still remains a problem. This shows the dilemma of matching the number of existing universities and other tertiary institutions with the surging population of youths processed from secondary education, seeking admission into the universities year after year. As pointed out by National Universities Commission cited in World Education Services (2017), between 1980 and 2017 the number of universities have grown from 16-152 (this includes private universities) which increased from 3 in 1999 to 68 in 2017. In 2013, 1.7 million candidates registered for centralized admission examination for available places of less than 400,000 in the existing institutions. This shows that over one million candidates could not have access to university education in the year 2017.

However, the problem may not only be due to lack of access but failures in tertiary institutions centralized examination which naturally screened out the unqualified candidates. For example, Table 4 shows the number of applicants for 2004/2005 to 2013/2014 and the number of candidates admitted each year.

Table 4. Unified tertiary matriculation examination applicants and admission into tertiary 2004-2014

\begin{tabular}{cccc}
\hline Year & No. of Applicants & Number Admitted & Percentage Admitted \\
\hline $2004 / 05$ & 841,878 & 122,492 & 14.5 \\
$2005 / 06$ & 916,371 & 76,984 & 8.4 \\
$2006 / 07$ & 808,422 & 88,524 & 11.0 \\
$2007 / 08$ & 911,653 & 107,370 & 11.8 \\
$2008 / 09$ & $1 ; 054,060$ & Not available & Not Available \\
$2009 / 10$ & $1,182,381$ & 148,000 & 12.5 \\
$2010 / 11$ & $1,375,652$ & 360,000 & 26.2 \\
$2011 / 12$ & $1,493,604$ & 400,000 & 26.8 \\
$2012 / 13$ & $1,503,889$ & 500,000 & 33.3 \\
$2013 / 14$ & 1,670833 & 520,000 & 31.1 \\
\hline
\end{tabular}

It is unimaginable that the shortfall may be attributable to inability of candidates to pass the qualifying examination but inadequate number of universities for more candidates to gain access into them. Similarly, National Universities Commission cited in World Education Services (2017) reported that in 2017, there were 107 Polytechnics, 27 monotechnics, 220 colleges in various specific disciplines, and 84 Teacher Training Colleges in Nigeria. This implies that more Universities are needed in Nigeria, in order to cope with admission demands and expectations. Interestingly, 1n 2019, the number of Universities in Nigeria increased to 170 comprising of 43 Federal, 48 State and 79 private Universities (Stephen, 2019). Besides, it is not only the establishment of more universities that matter, but to actually provide adequate resources to ensure effective teaching, research and community services which are the core mandate of university education (Okwori \& Okwori, 2007).

Other sources of providing access to education are through Polytechnics, Colleges of Education, Monotechnics, Research Institutes, Teacher Training Colleges and so on. It is regrettable to note that young people tend to think that university education is the ultimate, while other aspects of tertiary education are less significant. This is due to undue emphasis on University education by parents and the society. This has resulted in many youths who would have trained successfully as technicians, technologists and engineers in the Polytechnics and Colleges of 
Technology, to clamour for university admissions and meet with constant failures at centralized qualifying examinations. To correct this anomaly, due recognition should be accorded other levels of tertiary institutions so as to encourage young people to acknowledge their relevance to the society by seeking admissions into such institutions. These levels of education as pointed out by Adamu in Isuku (2007) helps in improving the graduates, increases their income earnings, improves occupational mobility, reduces unemployment level, enhances income distribution and hence improves social equity.

\section{Equal Educational Opportunities}

Whereas, access implies provision of adequate number of institutions to meet the admission demands of children and youths, equal educational opportunities refer to actual placement of qualified candidates in schools and programmes of studies irrespective of tribe, religion and race (Ofoha, 2010). This negates the introduction of quota system of admissions into tertiary institutions in Nigeria. Although the idea was good in principle, but in practice; many qualified youths could not gain admission into the universities because the allotted quota to their state(s) were exhausted due to the large number of qualified candidates seeking admission into available quota for that state. The consequence is that some states with fewer numbers of qualified candidates have excess quota while other states suffer inadequacy of quota allocation. This results in inequality in educational opportunities, which should be revisited and revised for the interest of all.

Education is the right of every citizen of Nigeria, but some persons who may not be opportuned to access formal education can take advantage of educational opportunities available to them in adult and non-formal education. There are myriads of opportunities in the non-formal sector, such as Basic Adult Literacy Classes, Education for School drop-outs in the evening continuing education centres, Education for Nomads, Distance Learning or Distance Education/Correspondence Studies, National Open University (NOUN) and so on.

These provide educational opportunities for youths and adults especially working class adults who may not be able to enroll in the formal education studies due to their jobs and family challenges. As pointed out by Etor (2011), "many workers and professionals need further education for various reasons, such as to update their knowledge, skills, work habits in line with changes in technology, and techniques of production, and other reasons. Thus, continuing education for this class of people through Open and Distance Learning (ODL) will help them avoid the high cost of part-time or full time studies along with other predicaments" (p.119). Educational opportunities abound for all Nigerians at various levels, but everyone is entitled to formal basic education as the springboard for all opportunities for other levels of education

\section{Resource Allocation to Education}

Resource allocation to education is the act of providing a reasonable percentage of the nations' or states, annual budget for the education sector of the economy. There do not seem to exist a clear-cut policy on resource allocation to education; otherwise referred to budgetary allocation for education in Nigeria, in view of the noticeable inconsistencies in figures or percentages annually. Consequently, there is a noticeable characteristic of resources in education which are not always enough to provide for all the educational services (Babalola, 2003). This often presents a serious problem in the actual budget implementation, with regards the needs assessment of each level of education. This raises the issue of distribution theory in resource allocation in education.

According to Babalola (2003) distribution theory is based on the notion that the optimum allocation of resources is achieved through the workings of the price system in which resources move from less profitable to uses that are more profitable, and from less important to more importance uses. This theory may apply wholly or partially in commercial and business enterprises, but not in education because each level of education is very important. Ideally, if there is a level of education that may be considered as most necessary and demanding, it is the basic education at the primary schools (Etor, Ekanem, \& Mbon, 2013), which is the foundation-laying level for all other levels to build on. To this end, more resources (human, money and materials) should be allocated to that level of education. What then should be the criteria for resource allocation to education?

\subsection{Criteria for Resource Allocation to Education}

The generally known outcry in the education sector is poor funding, inadequate infrastructures as major setbacks to increased access and breakthrough in the education sector. As pointed out by Akpan and Undie (2007), inadequate provision of human and material resources as well as infrastructural facilities due to poor funding resulted in the stipulation that admission of students should be based on available facilities, classroom, staff, equipment and materials. The implementation of such a proposal will further worsen access to education, hence, the need to explore some possible criteria for resource allocation in education. Since each level of education is very important and crucial for the socio-economic and political development of the state or nation, there should be comprehensive 
needs assessment of each level of education so as to justify its resource allocation annually. A typical example is a report by Abdullahi (2017) on Kaduna State budgetary allocation for education which was said to be the highest ever in that state which indicates the basis for that allocation as follows:

1) To raise poor (low) enrolment of pupils in primary schools.

2) To reduce high illiteracy rate in the state to the minimum.

3) To improve infrastructural facilities in all primary and secondary schools in the state.

4) To bridge the gap between those who have benefitted from formal education and those who have not.

This is a laudable example that should be emulated by other states and national levels in resources allocation for education. The prioritization of each level of education at state or national level would present the basis for objective resource allocation based on needs assessment of each level of education.

\section{Problems of Access and Resource Allocation to Education}

The problems of access to education are multi-dimensional and have serious implications for resource allocation to that sector. Besides, since the available public schools (at all levels) are unable to offer admission to all school leavers from one level of education to another, as well as new students seeking admissions, the problem of access becomes more pronounced and worrisome. It is in this regard that the governments of Nigeria encouraged and endorsed collaboration between government and private school proprietors to enhance expansion of access to education for children and youths who may not be absorbed into government-owned public schools.

Since the problem of access to education has a relationship with resource allocation to that sector, it becomes imperative to discuss problems in relation to poor funding, government attitude towards education, gender discrimination, Nigeria torture house, child-labour, insecurity in the country (Ene, 2007; Akpan \& Undie, 2007; Osim, 2016). These are briefly discussed as follows.

\subsection{Poor Funding}

Poor Funding has been a major problem of access to education because the inadequate financial allocation to the education sector over the years 2010-2019 could not ensure qualitative education for existing number of students in schools without reference to annual population growth and the number of students seeking admission to all levels of education. It is in this regard that Akpan and Undie (2007) stressed that when there is poor funding of schools, new facilities cannot be provided, and old ones cannot be expanded, and that makes students to learn under deplorable conditions. They also stated that due to poor funding, human, material resources and infrastructural facilities are always inadequate, hence, admission of students tend to be based on the availability of facilities, such as, classrooms, staff and materials. This creates additional problem of lack of access to admission for those who are qualified but cannot be admitted into schools.

\subsection{Government Attitude Towards Education}

Government attitude towards education in Nigeria over the years can be described as misplaced priority as evidenced in its previous annual budgeting allocations by various governments at the federal, state and local levels. As pointed out by Akumah, cited in Ene (2007), any government that budget's inadequate funds to education is bound to reap the dividends in all directions.

\subsection{Gender Discrimination}

Another problem that negatively affects access to education in Nigeria is gender discrimination and early childhood marriage. In the Northern part of the country, and even in some other parts of the country, the girl-child is not allowed to go to school because of the belief that their education would be an economic loss to their families as the girls would be married to other families. This is further worsened by giving the girl-child out to early marriage, and the dowry used in training the boy-child who will inherit the family property and continue the family lineage.

\subsection{Child Labour}

Child labour and trafficking is another serious problem of access to education by the affected children. It involves some parents using their children (boys and girls) to hawk and sell food and other items on the streets to augment family income, while other children are in schools learning. Child trafficking on the other hand involves forcefully taking a child away from parents by strangers known as traffickers and using them for economic gains to serve as servants, prostitutes outside Nigeria. As reported by Osim (2016), Nigeria is rated highest in child labour in Africa. These unfortunate children are denied access to education at primary and in some cases secondary education.

Another related aspect of child abuse of recent discovery in Nigeria is what is referred to as "Nigeria torture 
house", where it was reported by BBC (2019), that nearly 500 men and boys were rescued from a building in the Northern City of Kaduna where the detainees were alleged to be sexually abused and tortured. The report further indicated that the Nigeria Police said children as young as five years were among those in chains at what was believed to be an Islamic School. It was also reported that the children were forced to go and beg for money on the streets, and that the trend had continued for a long time before this discovery.

\subsection{Insecurity}

Insecurity in Nigeria is seriously militating against access to education in the country. For example, in 2014 over 200 secondary school girls in Chibok, Bornu State were kidnapped from the school by Boko Haram, and till date many of them are still missing. That incident affected access to education, as parents could no longer release their children to schools, as similar incidences occurred across the North-Eastern Nigeria. As reported by Onuoha cited in Osim (2016), many pupils, students and teachers have lost their lives and some seriously injured due to attacks on their schools by insurgents. This has negatively affected access to education in most parts of the country as the problem has spread all over the country.

\subsection{Corruption in Education}

Corruption is endemic in education sector, from the point of resource allocation at the Federal, states and local levels to actual implementation by the relevant government ministries and the institutional administrators at all levels. As pointed out by Transparency International cited in Douglas and Ezeugwu (2017), the seals and impression of corruption and corrupt practices are noticeable from the points of release of funds to the various ministries, parastatals and educational institutions where the funds are finally used. Osim (2016) pointed out that corruption is a major problem that has also impacted on the quality and access to education in Nigeria.

In the same vein, R. Etor and C. Etor (2018) stated that the problem of lack of probity in the management of budgetary allocations should be judiciously addressed at the end of each fiscal year to ensure proper accountability to enhance objective budgeting in the subsequent year.

The problem of resource allocation to education has many dimensions. The United Nations Scientific and Cultural Organization (UNESCO) proposed a bench-mark of 26 percent of a nations' annual budget as minimum for education to be implemented by all its member countries. Nigeria has never reached half that target as shown in Table 5.

Table 5. National budgetary allocation for education (2010-2019)

\begin{tabular}{cccc}
\hline Year & Total National Budget & Education budget & Education \% of Total \\
\hline 2010 & $40 \mathrm{trn}$ & $293 \mathrm{bn}$ & 7.19 \\
2011 & $4.22 \mathrm{trm}$ & $393 \mathrm{bn}$ & 9.31 \\
2012 & $4.74 \mathrm{trm}$ & $453 \mathrm{bn}$ & 9.15 \\
2013 & $4.92 \mathrm{trm}$ & $499 \mathrm{bn}$ & 10.15 \\
2014 & $4.69 \mathrm{trm}$ & $494 \mathrm{bn}$ & 10.54 \\
2015 & $4.49 \mathrm{trm}$ & $434 \mathrm{bn}$ & 10.71 \\
2016 & $6.06 \mathrm{trm}$ & $431 \mathrm{bn}$ & 7.92 \\
2017 & $7.44 \mathrm{trm}$ & $551 \mathrm{bn}$ & 7.41 \\
2018 & $8.60 \mathrm{trm}$ & $605.8 \mathrm{bn}$ & 7.04 \\
2019 & $8.92 \mathrm{trm}$ & $620.5 \mathrm{bn}$ & 7.02 \\
\hline
\end{tabular}

Sources: Adedigba (2018) and Udoma (2018).

A close observation of previous years' budgetary allocations for education in Nigeria show inconsistency and does not portray a clear rationale for such allocations. These cannot be compared to the 26 percent recommendation by UNESCO. The question is what really is the problem of implementing that UNESCO proposal? The problem may arise from one or more of the following:

1) Policy makers and planners for education, especially budgeting for education are non-professionals and educationists, hence, they cannot fully grapple with the nitty-gritty of educational needs at all levels.

2) The operators/implementers of budgetary allocation for education have never rendered their accounts of stewardship; hence there are no reliable data for subsequent budgetary outlay for objective resource allocation. 
When these issues are adequately addressed by all education stake-holders, the problems of access and resource allocation to education shall be reasonably solved.

\section{Prospects for Access and Resource Allocation to Education}

The federal government of Nigeria has licensed private individuals, voluntary organizations and other stakeholders in the education sector to establish schools, colleges and universities to enhance access to education in the country. Furthermore, Aluko and Bosun (2019) reported that the National Chairman of Academic Staff Union of Universities (ASUU) in Nigeria, Prof. Biodun Ogunyemi, said that the alarming out-of-school children in the country is a time-bomb, and that the cycle of inter-generational illiteracy must be broken. He concluded that the way out of it is for government to seek tangible solutions in providing infrastructure and suitable socio-economic conditions, otherwise we are just planting a time-bomb in the country and that as we remain at this level of poverty, and there will always be out-of-school children.

These cannot be compared to the 26 percent recommendation by UNESCO. The question is what really is the problem of implementing that UNESCO proposal? The problem may arise from one or more of the following:

1) Policy makers and planners for education, especially budgeting for education are non-professionals and educationists, hence, they cannot fully grapple with the nitty-gritty of educational needs at all levels.

2) The operators/implementers of budgetary allocation for education have never rendered their accounts of stewardship; hence there are no reliable data for subsequent budgetary outlay for objective resource allocation.

When these issues are adequately addressed by all education stake-holders, the problems of access and resource allocation to education shall be reasonably solved.

\section{Conclusion}

It is difficult to believe that Nigeria at 59 years of independence can still be lamenting over poor access to education as well as poor funding of education, arising from poor annual budgetary allocation for education. This shows that something is basically wrong or lacking in the planning and implementation processes. As earlier said, providing access to education is not only the business of government, but also that of private educationalists with proven years of practice and experience, not quacks (Egwu, 2009). Again, implementers of budgetary/resource allocation for education should be made to render accounts of their stewardship to justify the prudent management of funds allocated for education. This is why a fight against corruption should be extended to the education sectors at all levels. As pointed out by Osim (2016) corruption is a major problem that has also impacted negatively on the quality and access to education in Nigeria.

\section{Recommendations}

On the basis of the above submissions, it is hereby recommended as follows:

1) Everyone should be given equal access to education at all levels without discrimination.

2) The location of schools should be close to communities so that learners can access them easily.

3) Budgetary allocation to education should be made in conformity with the UNESCO recommendation of $26 \%$ of the nations' annual budget.

4) There should be adequate budgetary allocation for each educational programme in schools to enable heads of schools or departments procure appropriate and requisite instructional materials for effective teaching and learning.

5) Equal access opportunities should be given to all gender in the country.

6) Stricter laws should be enacted and enforced against child abuse and child trafficking.

7) Schools should be well secured against penetration by insurgents.

8) Policy makers and planners of education should be professionals and educationist who can make useful policies and plan education at all levels accordingly.

Those who operate and implement budget for education should be people of integrity, probity and accountability.

\section{References}

Abdullahi, F. (2017). Economic and fiscal update and education budget policy statement: 2015-2017. Education Review, 3(5), 36-42.

Adedigba, A. (2018). 2018 Budget: Buhari allocates 7\% to Education. 
Agile, H. E. (2018). Expanding Access to Education Opportunity in Nigeria: Matters Arising. International Journal of Scientific Research in Education, 1(3), 345-356.

Akpan, C. P., \& Undie, J. A. (2007). Access to University Education in Nigeria: Issues and problems. In J. B. Babalola, G. O. Akpa, A. O. Ayeni, \& S. O. Adedeji (Eds.), Access Equity and Quality in Higher Education. Ibadan: NAEAP (pp. 75-83).

Aremu, A. O. (2014). Improving access and quality education at the sub-national level. Paper presented at the third retreat of Nigeria Governor's forum at Eko Hotel and Suites on Friday March 4, 2014.

Babalola, J. B. (2003). Fundamentals of Economics of Education. In J. B. Babalola (Ed.), Basic Text in Educational Planning (1st ed., pp. 127-192). Ibadan: The Department of Educational Management, University of Ibadan.

British Broadcasting Cooperation. (2019). Nigeria 'torture house' Hundreds Freed in Kaduna Police Raid.

Douglas, O. N., \& Ezeugwu, M. C. (2017). Corruption in the education industry in Nigeria: Implications for national development. European Journal of Training and Development Studies, 4(1), 1-17.

Egwu, S. O. (2009). Roadmap for the Nigerian Education Sector Consultative Draft. Federal Ministry of Education, Abuja: Nigeria.

Ehiametalor, E. T. (2005). Issues, equity and private sector participation in the deregulation. In G. O. Akpa, S. U. Udoh, \& E. O. Fagbamiye (Eds.), Deregulating the provision and management of education.

Ene, A. C. (2005). Access and Equity in University Education in Nigeria: Issues and Trends. In G. O. Akpa, S. U. Udo, \& E. O. Fagbamiye (Eds.), Deregulating the Provision and Management of Education in Nigeria, National Association of Educational Administration and Planning (NAEAP) (pp. 55-62).

Etor, C. R., Mbon, U. F., \& Ekanem, E. E. (2013). Primary education as a foundation for qualitative higher education in Nigeria. Journal of Education and Learning, 2(2), 155-164. https://doi.org/10.5539/jel.v2n2p155

Etor, R. B. (2011). Distance Learning Management in Education. In S. U. Bassey, \& U. U. Bassey (Eds.), Management of Higher Education in Africa. Uyo: Abaam Publishing Company. (118-130).

Etor, R. B., \& Etor, C. R. (2018). Budgeting and budgetary allocation strategies for funding Nigerian education at all levels. In G. K. Etuk, E. Etudora-Eyo, \& C. R. Etor (Eds.), Fundamentals of education management 2 (pp. 199-206). Uyo: MK Prints.

Federal Ministry of Education Nigerian Education Indicators. (2016) Retrieved from https//www.nemis.gov.ng/download.fold/Nigeria

Federal Republic of Nigeria. (2013). 1999 Constitution of the Federal Republic of Nigeria (Revised Edition). Abuja: Ministry of Justice.

Federal Republic of Nigeria. (2014). National Policy on Education NERDC, Abuja.

Hindi, L. (2019, June 28). Foundation calls for free girl-child education. The Punch Newspapers.

Hornby, A. S. (2000). Oxford Advanced Learner's Dictionary of Current English. Oxford University Press.

Isuku, E. J. (2007). Providing an Enabling Framework for Increasing Access to Higher Education in Nigeria: The Evolving Role of Government. In J. B. Babalola, G. O. Akpa, A. O. Ayeni, \& S. O. Adedeji (Eds.), Access Equity and Quality in Higher Education (pp. 122-138). Ibadan: NAEAP.

Kufre, E., \& Kufre, E. (2013). The Child's Right. In C. R. Etor (Ed.), The Child: An Asset or a Liability (pp. 75-86). Calabar: Embor Ventures.

Matera, B. (2014). Equal Access to Education: A Challenge in Nigeria.

Ofoha, D. (2010). Equalizing educational opportunities in Nigeria through open and distance learning. A paper presented at the 6th Pan-Commonwealth Forum on Open Learning, at Kochi, India, 24th-28th Nov. Retrieved from donsofoha@yahoo.com.

Okwori, A., \& Okwori, A. G. (2007). Federal Character and Geographical Spread of Universities: Implication for Quality Access to University Education in Nigeria. In J. B. Babalola, G. O. Akpa, A. O. Ayeni, \& S. O. Adedeji (Eds.), Access Equity and Quality in Higher Education (pp. 91-97). Ibadan: NAEAP.

Osim, R. O. (2016). Expanding Access and Quality and Quality in Education in Nigeria. In, J. E. Okon, B. A. Akwegwu, \& E. S. Uko (Eds.), Emerging Issues in Educational Administration, Planning and Supervision 
(pp. 79-96). Calabar: University of Calabar Press.

Oyebade, S. A., Oladipo, S. A., \& Adetoro, J. A. (2007). Access to and equity in university education: A status report in Nigeria and sub-saharan Africa. In J. B. Babalola, G. O. Akpa, A. O. Ayeni, \& S. O. Adedeji (Eds.), Access, Equity and Quality in Higher Education (pp. 41-45). Ibadan. NAEAP.

Stephen, M. (2019). How many Universities are in Nigeria in 2019?

Udoma, U. U. (2018). Breakdown of 2019 Federal Government of Nigeria Budget Proposal: Public Presentation of the 2019 Budget of Continuity.

World Education Services. (2017). Education in Nigeria. Education System Profiles. Retrieved from https://wern.wes.org

Zwalchir, L. (2007). Access to Higher Education in Nigeria: The University of Jos at a Glance. In J. B. Babalola, G. O. Akpa, A. O. Ayeni, \& S. O. Adedeji (Eds.), Access, Equity and Quality in Higher Education (pp. 86-89). Ibadan: NAEAP Publishers.

\section{Copyrights}

Copyright for this article is retained by the author(s), with first publication rights granted to the journal.

This is an open-access article distributed under the terms and conditions of the Creative Commons Attribution license (http://creativecommons.org/licenses/by/4.0/). 